
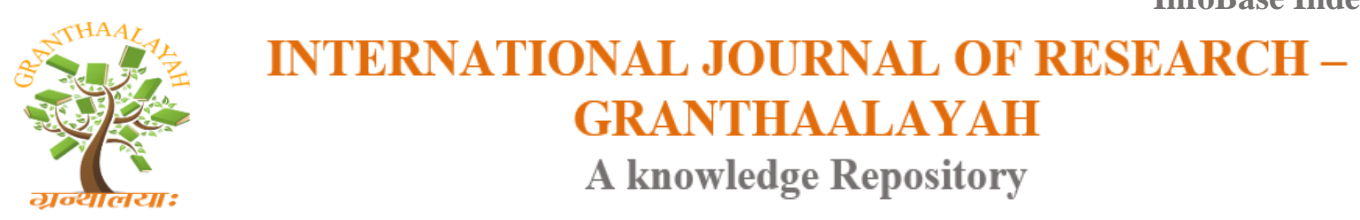

Social

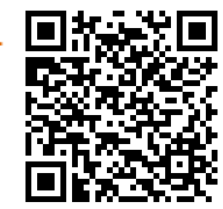

\title{
THE JOURNEY OF AN EMPOWERED WOMAN: THE LADY Z NARRATIVE
}

\author{
Ma. Salve R. Bunda ${ }^{1}$, Ann Marie B. Caburnay², Venus T. Patatag ${ }^{3}$, Junielou T. \\ Corporales $^{4}$, Elbert O. Talavera ${ }^{5}$, Mhel Emm Keith M. Talaboc ${ }^{6}$, Reynaldo B. Inocian ${ }^{2}$ \\ ${ }^{1-6}$ Department of Professional Education Scholars, College of Education, Cebu Technological \\ University- Main Campus, Cebu City Philippines, 6000; \\ ${ }^{2}$ Director, Institute for Research in Innovative Instructional Delivery (IRIID), Cebu Normal \\ University, Cebu City, Philippines, 6000
}

DOI: https://doi.org/10.29121/granthaalayah.v5.i5.2017.1869

\begin{abstract}
Lady $\mathrm{Z}$ was featured as an exceptional woman who achieved the pillars of her goals. Her memoir presented a consistent narrative of her life's challenges illumined a notable trait of courage and a remarkable strength to have excelled in education without a maternal guidance, surpassed the battle of being a single mom, and was able to balance time to combine career and advanced studies. The agents of Lady Z's success carved a persona of being independent and strong when her mom left her when she was a child. This event was repeated when her husband also left her and her children. These scenarios catapulted her success stories characterized with an illumined assiduousness to be resilient to life with strong faith in God. To Lady Z, becoming a successful individual necessitated to have possessed the values of being resilient in obtaining double jobs and by being emotionally strong. By being a teacher, Lady $\mathrm{Z}$ advocated to use life's examples in teaching and to become more humanistic in the journey of teaching. By becoming a teacher, Lady $\mathrm{Z}$ believed that being successful in life would start with a big dream. The most important piece of advice she yielded was to never lose a sight to educate a child.
\end{abstract}

Keywords: Education; Women Empowerment; Professionalism; Biographical Research; Close Encounter; Theme Illumination.

Cite This Article: Ma. Salve R. Bunda, Ann Marie B. Caburnay, Venus T. Patatag, Junielou T. Corporales, Elbert O. Talavera, Mhel Emm Keith M. Talaboc, and Reynaldo B. Inocian. (2017). "THE JOURNEY OF AN EMPOWERED WOMAN: THE LADY Z NARRATIVE." International Journal of Research - Granthaalayah, 5(5), 367-376. https://doi.org/10.29121/granthaalayah.v5.i5.2017.1869. 


\section{Introduction}

A career in education is a vibrant endeavor that continues to evolve in response to the challenges of the new millennium. Educational reform on the national, state, and district levels are an ongoing concern. The funding of education equitable educational opportunities for all children and finding the best instructional practices are just a few of the challenges that educators face in the years to come [1].

Education helps an individual to live a good life. Its role is to challenge inequality and dominant myths rather than socialize students into the status quo. Learning is directed toward social change and transferring the world, and through learning empowers students to challenge oppression in their lives [2] and live comfortably.

Everyone has their roles to play. When expectations are met things go smoothly because people think roles bring comfort [3]. In modern society, the roles of men and women become insignificant because of gender sensitization. Most women are able to partake in any activity or activities without thinking about the judgment of man, especially about education. To George Washington, "Education is the key to the golden door of freedom." It widens the views of men and women toward life and the things around them. To John Dewey, "It does not just only serve as a preparation for life's struggles and difficulties but it is life in itself." Education demands a great capacity of knowledge generation and dissemination and our capabilities to acquire in different areas of our experiences.

Through education, men and women are able to unleash the door of ignorance which somehow trapped them into the world of witlessness. Though it cannot change the directions of the wind toward an individual's goal; but it helps them to adjust the course they have always wanted. The object of education, after all, is to enlighten, to stimulate, to promote growth, and to motivate further development [4].

The teacher is the ultimate key to educational change and school improvement. The reconstruction of schools, the composition of national curricula, the development of benchmark assessments, all these things are of little value if school administrators do not take the teacher into account. Teachers do not merely deliver the curriculum. They develop, define it and interpret too. It is what teachers think, believe and do at the level of the classroom that ultimately shapes the kind of learning that young people experience [5].

"The last decade has been a philosophical battleground for many educators worldwide. Passionate about their work and committed to bringing out the best of their students, these frontline adjudicators of educational policies and pressures manage to overcome the personal impact of this and retain their core mission and commitment to what they believe is best for their students" [6].

Women play a special role in the battleground of education. Empowering women to participate fully in economic life across all sectors is essential to build stronger economies, achieve internationally agreed goals for development and sustainability, and improve the quality of life for women, men, families and communities [7]. The main advantage of women empowerment is 
that it enhances development of society. The money that women earn does not only help them and their family; but it does also help develop the society through taxes that government is collecting among women executives and workers in the industry. It also leads to more economic benefits not only to their individual families; but to the society as well. Unlike earlier days when they stay at home and do kitchen stuffs, nowadays, they roam outside and also earn money like their male counterpart.

Contributing to the economic growth of the country, women have to protect their interest and become more watchful about their rights against any form of discriminations. Trying to eliminate poverty in rural areas is a reality that most women are engaging, in order to maintain sustainable jobs with dignity.

Women empowerment helps women to stand on their own, to become independent and also earn for their family which can contribute to the country's economy and its greater impact to the changing civilization of the world. Women are increasingly participating in the national development process [8]. In this study, the subject uses education as a tool to face the ups and downs of Lady Z's life, as a woman with dignity. She is married at the early age; but she never sets aside the value and importance of education. At first, Lady $\mathrm{Z}$ works as a secretary at the Ombudsman's office and receives good compensation, complete benefits and ample time for her family. Lady $\mathrm{Z}$ goes back to school again because she feels that there is something lacking in her life, which she discerns that only education can fill her emptiness.

Lady $\mathrm{Z}$ chooses to take Masters in Public Administration because she has observed that most people especially the young once are not familiar about some standards of the society, which the moment they mature they are readily available to adapt these standards, which the school and other social institutions in the society would expect them to perform. She knows that teaching is not an easy task because it needs a lot of efforts; but she does not lose her spirit. At the beginning of her teaching career, she feels a lot of mixed emotions but the good thing is she has found that teaching is fun. "Life as a teacher is a paradox." A person will have to be strict and loving at the same time. We may feel exhausted and exhilarated; but the best of all we receive more than we ever give.

\subsection{Review of Related Literature}

Education helps a woman to live a good life. Her identity as an individual would never get lost. She can read and learn about her rights. Her rights would not get trodden down. The life or condition of women would improve a lot, if we take a broad outlook in the field of female education [8].

Knowledge is indeed powerful. In the course of more than 2000 years of our rich history, one can attest that knowledge is a powerful tool that allows an individual not only to survive, but also to grow as a person in the society where he/she belongs. Due gratitude to the great thinkers of the past who manifest strong personalities to fight for the person's basic right to education, we presently enjoy the availability of education in various levels. 
Education is undoubtedly one of the best agents for social change, economic development and prosperity in the country. Getting a good education is the key to our growth, as it allows knowledge to be advanced from generation to generation. People with an education, regardless of whether it is in college or in trade, have a many more employment options than an unskilled worker. The credits and achievements we make in our educational field help to put us on the right track for a great job.

Education boosts an individual's independence, and allows him/her to make a living once he/she has earned a degree, and becomes a positive member of the society. People who have studied, and spent time to learn specialized skills are usually rewarded with a higher salary, and are more financially secure than their uneducated counterparts. Being educated helps establish independence, and gives a reliable trust in our instincts and better knowledge to make decisions. It allows us to make decisions based on logic and reason, and create our own responses rather than simply following the pack [9].

Teachers play multiple roles. They are learners, constantly taking classes and attending professional development sessions to learn the latest best practices for effective teaching. Many teachers regularly collaborate with one another to gain new ideas for teaching, planning gradelevel instruction and combining subjects to enhance the learning experience. They analyze test results and other data to help determine the course of their instruction and make changes in their classrooms. They also design lesson plans to teach the standards and provide engaging activities, while taking into account each student's interests and instructional needs [10].

Professionalism means being the very best teacher that one can become every day. When teachers choose to conduct in a professional manner, they send the message that they are in control of their classroom and themselves; they earn the respect of their students and colleagues in the process. Although, it is not always easy to be a professional educator, especially when they are just starting out, professionalism is one of the best tools that they have to possess to prevent stress [11].

Women have always enjoyed greater equality in Philippine society than in other parts of Southeast Asia. The Philippines ranks $5^{\text {th }}$ country in the world that promotes the sensitivity to women [12]. A woman's rights to legal equality and to inherit family property have not been questioned. Education and literacy levels in 1990 are higher for women than for men. President Corazon Aquino often is given as an example of what women can accomplish in Philippine society. Gloria Macapagal Arroyo adds in the list, as the second president of the Republic of the Philippines. In 88 years of history in Philippine Senate since 1947, 20 female senators are in the roster to complete 237 of which 217 are males [13] and a countless women are serving in the Philippine Congress, in judiciary, in industry and in the corporate world and in the academe. This shows the assertiveness of women's power in the Philippines.

The appearance of women in important positions, however, is not new or even unusual in the Philippines. Filipino women, who are usually called Filipinas, have been senators, cabinet officers, Supreme Court justices, administrators, and heads of major business enterprises. Furthermore, in the early 90 s women are found in more than a proportionate share of many 
professions although they are predominated in domestic service (91 percent), professional and technical positions (59.4 percent), and sales (57.9 percent) [14].

They make up over half of the Philippine population. Their contribution to society has been incalculable, but disparities clearly remain between the fulfillments of their needs, on one hand, and the services and protections afforded them by the state, on the other hand [15].

\subsection{Objectives of the Study}

This study featured how an exceptional woman (Lady Z) has achieved the pillars of her goals. It sought to: (1) describe her memoir before her triumph, (2) analyze the agents of her success stories, (3) extrapolate her values toward life's difficulties and in teaching, and (4) interpolate a perception of her values toward the teaching profession.

\section{Materials and Methods}

\subsection{Research Design}

This is a biographical and portraiture research design which looked into the life of an exceptional woman immortalized by the name 'Lady Z,' in order to preserve her confidentiality. Biographical Research, based on Roberts, is a specific type of qualitative research design that uses stories of an individual to understand the social enigma or complexity of life. Based on Bueno, portraiture design is painting a vivid portrait or story of the chosen subject. Lady Z, as the central subject of this study was chosen through opportunistic and criterion samplings. She was selected with the exclusive criterion of being a powerful woman in her family, abandoned by her mother when she was child and being deserted by her husband with her kids. Her narratives were recorded, clustered, and analyzed. Illuminating themes were drawn from her narratives, in order to visualize a distinct character of a woman of courage.

\subsection{Research Tools}

Unstructured interview guide was used as the primary instrument in the study. A close encounter of the subject was scheduled based on the most available time set by the subject. This was done using the proper protocol. A letter of consent was sent through an electronic mail and seconded with a direct phone call to ensure whether the letter was received. The narratives were recorded electronically as field notes. Before the actual one-on-one interview, informed consent was signed by subject with all the requirements in it were made clear for her. After the aforesaid interview, a token of recognition was given to her as gesture of trust afforded to the researchers during the conduct of the interview. 


\section{Results and Discussions}

\subsection{On Lady Z' Memoir}

\section{Theme 1: A Nobility of Success without a Maternal Guidance}

Lady $\mathrm{Z}$ was a 52-year old teacher, who grew up with her father since her mother left her when she was young. She was an intelligent, kind and responsible daughter. Though struggles in life almost hinder her journey to success, she held on with her dreams and positive outlook in life. She graduated as a Class Valedictorian in Elementary and Secondary Education; and Cum Laude when she graduated in college with the course of Bachelor of Arts in English. She took the Civil Service Examination and became one of the topnotch. Lady Z's narrative disproved a popular success accounts' with a mother as the most influential figure in the educational attainment of the child. Her success was greatly influenced by a father who took care of the maternal responsibility in the home, in the absence of a mother, who abandoned the rest of her siblings.

\section{Theme 2: The Battle of a Single Mom}

After she graduated in college, she worked as a private secretary. At the age of 18 she got married and blessed with two daughters and three sons. For some, being married is a lifetime commitment but not for Lady Z. The couple had several misunderstanding and reached the point that they had to decide to separate. Her agony did not end there; she had to feed her children and tended to their daily needs. To top it all, she had to allow her children to continue to communicate with their father despite her broken relationship with him. She raised her children and sent them to school on her own. Lady $\mathrm{Z}$ never stopped dreaming nor surrendered despite the difficulties she had throughout her life. Lady $\mathrm{Z}$ was a classic example of woman's liberation and assertiveness in assuming the role of her husband's responsibilities to raise her kids.

\section{Theme 3: Combining Career and Advanced Studies}

Every click of the watch is a treasure she never ignores even once since her goal is clear, that is to pursue her career and to never stop learning. She took up her Master's Degree specializing in Public Administration for two years. She went further and finished her Doctorate Degree in Public Administration. After successive huge successes, she decided to apply as a guest lecturer in one of the state universities in Cebu City and was hired. In 2012, she began to teach various courses to post graduate students. A strong woman with a great heart and precious desires became an inspiration to her children as well as to other people in the community.

\subsection{Agents of Success}

\section{Theme 4: Being Assiduous and Faithful Conquers all Challenges}

In every challenge there is a reason behind that we cannot even foresee nor foretell unless we take the courage to go deeper and cherish the pain and sweetness of fighting the challenges in life. Lady $\mathrm{Z}$ never thought of giving up despite the biggest and hardest difficulties she had in life. Having been neglected by her husband, she has to move on and face the reality. She had to 
double her effort in working, in order to support her children. Doing two jobs at the same time had never been easy - being a mom and the primary earner of the family. All she had is a total trust and faith in God. All of these became her inspiration. Her dreams pushed her not to be negative and never thought of giving up. The Filipino Woman today are not only doing household chores and child rearing, but are also becoming active income contributors according to National Commission on the Role of Filipino Women in 1995 [16].

\subsection{Values to Life's Difficulties}

\section{Theme 5: Resiliency in Maintaining Double Jobs}

While working as a public servant in the Office of the Ombudsman Visayas, Lady Z's desire to impart her knowledge and wisdom to other people never leaves her heart. She knew she was called to educate students. At one point, she had made a great leap in her career and applied for a teaching position. With no doubt, she became a guest lecturer in one of the state universities in Cebu City, Philippines. She started teaching in 2012 in various courses to Graduate School students after her office hours. She did this in order to prevent double compensations and to become a law-abiding citizen.

\section{Theme 6: The Unquestionable Strength of a Woman}

A strong woman with a great heart and precious desires, Lady $\mathrm{Z}$ was an inspiration to her children and also to other people. When asked what made her decide to venture into teaching, she shared "Not only that I find it more exciting and challenging, I am also able to gain knowledge from my students." Her being a teacher was a means that enables her to gain additional income and to be more aware of the present set up and methods of education. Moreover, she wanted to share her experience of learning to her students in order to inspire them to finish their post graduate studies. Her personal witness to becoming a fulfilled woman-being a mother, a public servant, and an educator-amidst suffering, poverty, humiliations, and frustrations, was a sweetest way of living a virtuous life. Lady Z's unquestionable strength was a barometer of her success in both family and career life.

\subsection{Values of Becoming a Teacher}

\section{Theme 7: Teaching by Life's Examples}

Lady $\mathrm{Z}$ was a living example of an educator who had in mind with social justice as the end goal of her educational content. Nancy Gallavan, a professor of teacher education at the University of Central Arkansas, pointed out the relevance of integrating in the educational content what is most significant and meaningful to the students' lives such as determining how to challenge social forms of oppression that limit opportunities for themselves, their families, and communities [17]. Lady Z, who faced various limitations to propagating her own personal needs and her family, was best able to share her success to her students. This exemplified teaching by example, one of the most powerful ways in inspiring students to be career driven in achieving their dreams, to persevere, and to give their best in all circumstances. 
According to Rogers, teachers must spend considerable time and effort building positive relationships with students, allowing their authenticity, genuineness, and caring to naturally shine through. When these human dimensions are cultivated, a teacher can genuinely act as a "person, not a faceless embodiment of a curricular requirement, or a sterile pipe through which knowledge is passed from one generation to the next" [4].

Rogers adds, "The challenging part of teaching profession is the assurance that your students are able to internalize the knowledge that you as a teacher cascaded or imparted to them." Furthermore, it is when the teacher truly desires that the student would be able to integrate the acquired knowledge into their life in the form of personal choices, their daily routines, interpersonal relationship, and in their journey in becoming a better person in the society, that makes teaching profession truly a vocation rather than just a mere occupation.

\section{Theme 8: Teaching is a Humanistic Journey}

Zahorik believes that each education major has a preferred way of teaching and that teacher educators should help them determine their favorite style to become more effective in their chosen career [18]. Learning to teach involves a range of practice skills and a subtle appreciation of when and how to apply them. Whether we like it or not, how we teach and how we learn to teach is bound up with our own personality, philosophy and values [5]. Lady Z finds teaching the first time as very interesting since her students are her inspiration as she goes through her journey. The decision to be a teacher is one with far-reaching consequences. Teachers are committed themselves not only to a lifestyle in which they must become an expert in their field but also to one in which they have tremendous incentives to be the well-adjusted, fully functioning and satisfied human being they can possibly be [19].

\subsection{Lady Z' Piece of Advice}

\section{Theme 9: Success in life starts with a Big Dream}

It had been a tough job for Lady $\mathrm{Z}$ before she finally reached the peak of her success. It took her twenty two years before she had finally completed her studies and got a stable job. For her, a definition of successful life was a fulfilled educational attainment with a happy contented family. This had been her motivation that she would be enjoying most of the time, after the various 'turns and twists' in her life. She shared that "the first step on the path to success is to dream." Dream big, take steps in achieving your goals, move forward, and be ready to stumble and to rise again. Never lose sight of that big dream.

\section{Theme 10: Never Lose Sight to Educate}

For those who dream to become educators someday, patience, endurance, positive outlook, and understanding are interrelated virtues that one has to acquire. To Lady Z, "People can label you of being 'terror,' 'strict,' 'rigid,' etc., but let not these deter you in achieving your dream. You also have to unceasingly acquire knowledge for that is your job --- to educate." She added that one should also be prudent and consider practical means in achieving ones dream: proper management of resources, time, and efforts. To her, her experience in teaching was her best 
teacher. Teachers manage the learning space, time, materials, and the mental, physical, and emotional state of individual, partners, small groups, and large groups. Effective teachers must be effective managers [20].

Things that people enjoy and view as sources of pleasure stay with them throughout their lives [21] because self-direction is important component of motivation. The tough experience of Lady $\mathrm{Z}$ challenged her not to give up on her dreams despite raising her four children on her own without depending on her husband. She finished her highest educational attainment and finally reached the peak of success after twenty years of waiting. As one of those mothers who strived hard for the welfare of her children, she was ready to embrace all struggles and willing to give up her pride for the benefit of her future career. She was a great example of a strong woman and a role model to all single mothers who, even though they were unsuccessful in having a complete family, they could still improve the situation and can transform it into a harmonious and strong family despite the absence of a father and a husband.

\section{Conclusions \& Recommendations}

Lady $\mathrm{Z}$ was featured as an exceptional woman who achieved the pillars of her goals. Her memoir presented a consistent narrative of her life's challenges illumined a notable trait of courage and a remarkable strength to have excelled in education without a maternal guidance, surpassed the battle of being a single mom, and was able to balance time to combine career and advanced studies. The agents of Lady Z's success carved a persona of being independent and strong when her mom left her when she was a child. This event was repeated when her husband also left her and her children. These scenarios catapulted her success stories illumined assiduousness to be resilient to life with strong faith in God. To Lady $\mathrm{Z}$, becoming a successful individual necessitated to have possessed the values of being resilient in obtaining double jobs and by being emotionally strong. By being a teacher, Lady $\mathrm{Z}$ advocated to use life's examples in teaching and to become more humanistic in the journey of teaching. By becoming a teacher, Lady $\mathrm{Z}$ believed that being successful in life would start with a big dream. The most important piece of advice she yielded was to never lose a sight to educate a child. This research will be limited for validation of teachers' struggle with the pressure between personal and professional life, family versus career. This may provide a concrete exemplar to the reality that the various dimensions of a teacher's individuality relative to his/her role in the society as a family member, as an educator, and most of all as an individual who seeks fulfillment in his/her way of living, present no opposition towards his/her own personal growth and happiness. Thus, a close encounter of novice and expert teachers will be recommended to find out similar parallelisms of this study.

\section{References}

[1] Ebert, Edward S. et al. SCHOOL AN INTRODUCTION TO EDUCATION. Wadsworth 20 Davis Drive Belmont, CA 94002-3098 USA

[2] Weimer (2002). LEARNER- CENTERED TEACHING. Jossy-Bass a Wiley Company 989 Market Street San Francisco, CA 94103-1741

[3] Bruno, Holly Elissa. LEADING ON PURPOSE. Mc-Graw Hill, Mc- Graw Hill Companies, Inc. 1221, Avenue of the Americas, New York, NY 10020

[4] Zehm, Kottler (1993). ON BEING A TEACHER. THE HUMAN DIMENSION. Corwin Press Inc., A Sage Publications Company 2455 Teller Road Thousand Oaks, California. 
[5] Dillion and Maguire (2001). BECOMING A TEACHER, ISSUES IN SECONDARY TEACHING. Open University Press Celtic Court 22 Ball Moor Buckingham MK18 IXW

[6] Korthagen, Kim, Greene (2013), TEACHING AND LEARNING FROM WITHIN, A CORE REFLECTION APPROACH TO QUALITY AND INSPIRATION IN EDUCATION. Retrieved May 28, 2016, Routeledge 711 Third Avenue, New York, NY 10017

[7] WOMEN EMPOWERMENT PRINCIPLES. Retrieved May 3, 2016, form UN Women: http://www.unwomen.org/en/partnerships/businesses-and-foundations/womens-empowermentprinciples\#sthash.yQIcc97G.dpuf

[8] Sehgal, Rohit (2015).SHORT ESSAY ON IMPORTANCE OF WOMEN EDUCATION. Retrieved May 2, 2016, from http://www.importantindia.com/17061/essay-on-importance-ofwomen-education/

[9] Travis, Bennett. THE MANY ADVANTAGES OF EDUCATION. Udemy Blog. Retrieved May 22, 2016. https://blog.udemy.com/advantages-of-education/

[10] Zeiger, Stacy. WHAT IS THE ROLE OF TEACHERS. Retrieved May 22, 2016. Demand Media.http://work.chron.com/role-teachers-education-8807.html

[11] Thompson, Julia G. THE FIRST-YEAR TEACHER'S SURVIVAL GUIDE. A Wiley Imprint. 989 Market Street, San Francisco CA 94103-1741

[12] Villaganas, A, Giango, W., Basubas, E. and Villaganas, V. (2016). European Scientific Journal

[13] Caronan, R. (2015). GENDER DIVIDE IN THE PHILIPPINE SENATE: 217 males, 20 females in 88 years. The PCIJ Blog, Date Retrieved: May 30, 2017 http://pcij.org/blog/2015/03/07/gender-divide-in-the-ph-senate-207-males-18-females-in-88-years

[14] Dolan, Ronald E. (1991). THE ROLE AND STATUS OF WOMEN. Retrieved May 2, 2016 from Philippines: A Country Study. Washington: GPO for the Library of Congress, 1991: http://countrystudies.us/philippines/44.htm

[15] Shahani, Lila (2015). ENGENDERING DEVELOPMENT: THE STATUS OF WOMEN IN THE PHILIPPINES. Retrieved May 2, 2016 from philstar.com: http://www.philstar.com/opinion/2015/03/02/1428959/engendering-development-status-womenphilippines

[16] Selasa. GENDER ROLE OF FILIPINO WORKING WIVES IN METRO MANILA. Retrieved May 28, 2016. Bertapyschologycorner.blogspot.com/2010/12/gender-role-of-filipino-workingwives.html?m=1

[17] Gallavan, Nancy P. (2010), MULTICULTURAL EDUCATION, FIFTEENTH EDITION. The McGraw Hill Companies, Inc. 1221 Avenue of the Americas, New York, NY 10020

[18] Cruickshank et al. THE ACT OF TEACHING FIFTH EDITION. The McGraw-Hill Companies, Inc., 1221 Avenue of the Americas, New York, NY 10020

[19] Kottler, Jeffrey A. et al. THE TEACHER'S JOURNEY, THE HUMAN DIMENSION. Corwin A SAGE Company 2455 Teller Road Thousands Oks, California 91320

[20] Erwin, Jonathan C. THE CLASSROOM CHOICE. 1703 N. Beauregard St. Alexandria, VA 22311-1714 USA

[21] Kame'enui et al. VOCABULARY INSTRUCTION. The Guilford Press, A Division of Guilford Publication, Inc. 72 Spring Street, New York, NY 10012

\footnotetext{
*Corresponding author.

E-mail address: inocian03@yahoo.com
} 